\title{
Rewitalizacja przestrzeni w historycznej tkance miasta. Walencja
}

\section{Regenerating space within the historic tissue of the city. Valencia}

\section{Streszczenie}

Artykuł przedstawia efekt warsztatów studenckich zorganizowanych pod tytułem „Rewitalizacja przestrzeni publicznej i za

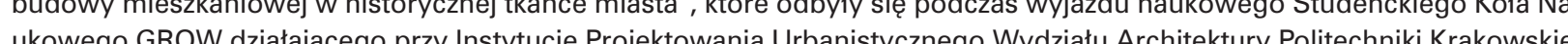
do Walencii. W wyniku warszzatów powstało sześć projektów dyplomowych inżynierskich. Organizatorami wydarzenia były Politechnika Krakowska we wspótpracy z uczelnia CEU Cardinal Herrera University w Walencii. Warsztaty posłużyły wykona niu analiz majacych na celu przyblizenie charakterystyki miasta, w szczególności jego cześci historycznej oraz wizij lokalnych przedstawionych przez uczelnie hiszpańska dzijłek, staing

\section{Abstract}

This article presents the results of a student's workshop organised under the title "Regeneration of housing and urban space within the historic tissue of the city", which took place during an academic trip of the GROW Students' Academic Club-which is affiliated with the Institute of Urban Design of the Faculty of Architecture of the Cracow University of Technology - to Valencia, Spain. Six Engineer's diploma projects were prepared as a part of the workshop. The event was organised by the Cracow University of Technology in cooperation with the CEU-the Cardenal Herrera University in Valencia. The workshop was used to perform analyses aimed at familiarising students with the characteristics of the city, particularly its historic section, as well as
performing on-site visits to plots presented by the Spanish university, which were later used as sites for the student projects.

Stowa kluczowe: warsztaty studenckie, rewitalizacja przestrzeni publicznej, Walencja
Keywords: students' workshop, revitalisation of urban space, Valencia

\section{WSTĘP}

Na przełomie października i listopada 2018 odbyły się Międzynarodowe Warsztaty Studenckie zorganizowane ki Krakow w Walencii Wydarzenie zatytu Cardene byto Rewitalzacja przestzeni publicznej i zabudowy mieszkaniowe w historycznej tkance miasta". Uczestniczacy w warsztatach studenci zapoznawali sie z historia architektura i urbanistyka Walencji. Przedstawiciele Universidad Cardenal Herrera CEU mónili o problemach dotyczacych miasta, jego specyfice i potrzebach. Studenci wykonall badania in situ $i$ analizowali przestrzenie publiczne za równo w starej jak i w nowej czesści Walenciji. Badal przykłady historycznej i współczesnej architektury oraz jej wpływ na funkcjonowanie miasta. Najbardziej szczegółowe analizy przeprowadzili, ze względu na charakter badań, w Starym Mieście, obszarze o największej aktywności turystycznej i najbogatszej historii. Efektem badan stały się projekty architektoniczne budynków użyteczno-

\section{INTRODUCTION}

At the turn of October and November 2018, an Interational Students' Workshop was organised in Valencia as a part of inter-university cooperation between fechnology and the Universidad Cardenal Herrera tissue of the city". The students who participated in the workshop were familiarised with the history, architecture and urban lavout of Valencia. Representatives of the Universidad Cardenal Herrera CEU discussed the problems that pertain to the city, its specificity and is needs. The students carried out on-site studies and analysed the public spaces of both the new and old part of Valencia. They studied cases of historical and contemporary architecture and its impact on the functioning of the city. The most detailed analyses, due to the character of the research, were performed in the Faculty of Architecture of the Cracow University CEU in Valencia, Spain. The event was named "Regeneration of housing and urban space in the historic Old Town, an area of the greatest tourist activity and ści publicznej zlokalizowane w północnej części stareprojekty, $w$ centrum Walencj. Dzialki przeźci tradycyjn zabudową mieszkaniową w postaci gęsto posadowionych kolorowych kamienic. Na tym obszarze dominuja obiekty o charakterze historycznym. Dostępność komunikacyjną zapewnia transport publiczny, samochodowy lub rowerowy.

Publikacja ma na celu wykazanie na ile badania przeprowadzone przez studentów in situ, wizje lokalne, zapoznanie się z miejscowymi uregulowaniami, možliwościam potrzebami mieszkanców zaprezentowanymi podczas rozmów i prezentacji przygotowanych przez osoby związane $z$ Walenca, pomogly w realizacji projektów $i$ odpowiedzi na postawione zadania.

\section{MIEJSCE - WALENCJA}

Walencja jest trzecim co do wielkości miastem w Hidrugim najwiekszym w tym kraju portem. Zamieszkuje ja osiemset tysiecy mieszkańców, a wlicza jac obszary aglomeracyjne - ponad 15 miliona Miasto zajduje sie w środkowo-wschodniej czési Pótwyspu lberyjskiego.

(2)

Walencja powstała w roku 138 p. n. e. jako kolonia rzymska. Przez ponad pięć wieków pozostawała pod panowaniem arabskim, potem została zdobyta przez króla Aragonii Jakuba I Zdobywcẹ. Zaczęła przekształcać sie W miasto chrzescijanskie. W 1240 otrzymała przywileje, które zapoczatkowały jej szybszy rozwój gospodarczy i kulturalny. Do 1707 roku była stolica królestwa będącego pod zwierzchnictwem Aragonii. W latach 1812-1813 panowanie nad miastem objęły wojska francuskie, a w czasach hiszpanskiej wojny domowej Walencja stanowila siedzibę rządu republikańskiego.[1] W roku 1957 nawiedzila miasto ogromna powódź. Wylała rzeka Turia, powodując śmierc osiemdziesięciu ludzi i niszcząc duzą częsć miasta.[2] Konsekwencją stała się przeprowadzona w 1960 roku zmiana biegu rzeki. W ten sposób uwolniony został rozległy, około 110 hektarowy obszar w srodku Walencji. Po licznych konsultacjach społecznych, dawne koryto rzeczne przeprojektowano na ciągnący się wzdłuź całego miasta, na długości prawie siedmiu kilometrów podłużny park, który sta się unikalny w skali swata obszarem rekreacyjnym. Ogrody Turii (hiszp. Jardin del Turia) rozpoczynają sie od Bloparku, by potem często zmieniać swoją stylistykę W parku, oprócz traktów pieszych, znaiduja sie instalacje boisko do lekkotletyki, gry w rugby oraz do pitki nożn, zewnetrzne sitownie, place zabaw, skatepark "Gulliver", akweny wodne oraz pałac muzyki. Domkniecie ogrodów od strony zachodniej stanowi Miasteczko Sztuki i Nauki. Jest to odważny i bardzo kontrowersyjny projekt Santiago Calatravy, przy wspótpracy z Felixem Candela [3]

\subsection{Stare Miasto}

Stare Miasto obfituje w największą w Walencji ilośc obiektów historycznych oraz muzeów. Liczne w tej lokalizacji hotele oraz usługi takie jak Airbnb, spowodowały odpływ ludności rodzimej.[4] Wiele budynków jest with the richest history. The effects of these studies of public buildings located in the northern part of the Old Town, in the centre of Valencia. The plots selected as project sites are predominantly surrounded by traditional housing buildings in the form of denselyplaced, colourful tenement houses. The area is domnated by historical buildings. Public, vehicular and bicycle transport provide circulation and accessibility. The publication is meant to demonstrate the degree to which the on-site studies and visits, as well as the familiarisation with local conditions, possibilities and the needs of residents that had been presented dur ing discussions and presentations prepared by perpons associeded with Valencia, helped in dranting the projects and answering a set of questions.

1. LOCATION-VALENCIA

Valencia is Spain's third-largest city and the country's second-largest port. It is inhabited by 800000 residents, while its metropolitan area has a population in excess of 1.5 million. The city is located in the central-eastern section of the Iberian Peninsula.

Valencia was founded in $138 \mathrm{BC}$ as a Roman colony. It remained under Arabic rule for over five centuries, until it was conquered by Jacob I the Conqueror, the king of Aragon. It started to transform into a Christian city. In 1240 it received town rights, which stimulated aster economic and cultural growth. It was the capital of a kingdom that remained subjected to Aragon up to 1707 . In the years $1812-1813$, rule over the city was seized by French forces, while during the Spanish civil war it was the seat of the republican government. [1] wh 1957 the city was affected by an immense flood. The Turia River overflowed, causing the death of eighty people and destroying a large portion of the city. [2] As aconsequence, the course of the river was changed in 1060. Because of this, an extensive, 110-hectare area was freed up for development in the centre of Valencia. After numerous rounds of public consultations, the tretch iverbed was redeveloped into a long park that stretches across the entire city over a length of almost

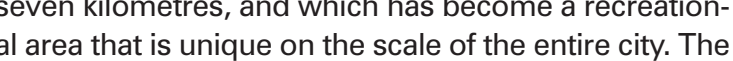
Turia Gardens (Jardin del Turia in Spanish) start with the Biopark, often changing in style, which helps their users to orient themselves within space. In the park, apart from pedestrian paths, there are also art installations, bicycle paths, running trails, a track and field course, a rugby and football pitch, outdoor gyms, playgrounds, the "Gulliver" skate park, water bodies and a palace of music. From the west, the gardens culminate in the Cly of Ans and Sciences. Ih is a bold and signed in cooperation with Felix Candela. [3]

\subsection{The Old Town}

Valencia's Old Town has the greatest wealth of heritage buildings and museums in the city. The large number of hotels and other lodging services such as Airbnb have led to a flight of its original inhabitants. 
częściowo wyburzonych, bądź zaniedbanych, a brak obiektów uzyteczności publicznej spowodował rosnacą niechęc mieszkaniców Walencji do tej cześci miasta. Równoczesnie, wybudowanie Miasteczka Sztuki i Nauki spowodowało znaczny odpływ również i turystów z Walenckiej starówki powodując coraz powszechniejsze zjawisko jej "Wymierania". Ostoja mieszkańców Walenc zdaje się być jeden z najbardziej charakterystycznych obiektów historycznych jakim jest Plaza del Mercado Żelazno-szklana ośmioboczna konstrukcja hali targowej powstała pomiędzy 1910 a 1926 rokiem. Oprócz turystów przyciagga tłumy krzątających się między straganami Hiszpanów.[5] Niezwykłym atutem jest również otaczający stare miasto park powstały w korycie płynace tam kiedyś reki Tuni. Po intensywhym wylewie w 195 roku powstaly plany wysuszena starego koryta rzek jednak o zaprojektowanie tam ogromnego lineawno parku orrajaje wspomnianego wcześniej Miasteczka Sztuki i Nauki $\mathrm{Na}$ terenie Starego Miasta dominuje ciasna zabudowa w postaci cztoro, pieciokondygnacyinych kabudoz umieszczonymi na parterze funkcjami przed wsystkim takimi jak kawiarnie i restauracje. Zabudowa starego miasta jest też niezwykle kolorowa. Kamienice pokryte sa tynkiem o bardzo jaskrawych barwach od źóttego który zdaje sie być w tym mieście kolorem dominujacym, przez róże i błękity. Popularne jest tutaj ozdabianie ścian kamienic oraz np. spodów płyt balkonowych kolorowymi płytkami ceramicznymi przedstawiającymi motywy roślinne, ale niekiedy również zwierzęce i ludzkie. Jest to cecha charakterystyczna dla tego miasta, ponieważ słynęło one kiedyś produkcji ceramiki.

Kolor i dekoracja nadają miastu niezwykłej energi i w pewien sposób lagodzą gęstośc zabudowy - odległości między ścianami budynków dochodzą nawet do $3 \mathrm{~m}$ (jest to minimalna odlegtość ustanowiona prawnie).

\section{REWITALIZACJA PRZESTRZENI PUBLICZNEJ I ZA-} BUDOWY MIESZKANIOWEJ W HISTORYCZNEJ TKAN-

Analizy urbanistyczne kilku zdewastowanych i podupadłych lokalizacji w obrębie Starego Miasta Walencji do prowadziły do ostatecznych konkluzji, wśród których n pierwszy plan wysunęły się dwie. Otóż, w historyczne tkance miejskiej Walencji brak zieleni oraz przestrzen ich spotkań i zakty spót studentów Wydziatu Architektury Politechniki Krakowskiej projekty miaty więc za zadanie rozwiazać ów problem i zaproponować miastu ciekawe, potrzebne i funkcjonalne projekty.

2.1. Zespół dwóch budynków usługowych $[6,7]$ W skład projektowanego zespołu wchodzą dwa nowe budynki: Centrum Nowych Technologií'. oraz Mediatetwie istniejacej zabudowy, swoja kubatura domykając plac oraz kontynuując istniejące pierzeje. Część urbanistyczna projektu została opracowana $w$ dwuosobowym zespole $^{3}$, a podstawowe założenia oraz analizy stanu ist-
[4] Many buildings are either partially demolished or mercial buildings has caused the inhabitants to increasingly shun this part of the city. At the same time, the construction of the City of Arts and Sciences has also caused a significant redirection of tourists from the Old Town, leading to the increasingly prevalent phenomenon of it appearing deserted. One of the most distinctive historical sites, Plaza del Mercado, appears to be a foothold of Valencia's residents. The iron and glass octagonal market hall structure was built between 1910 and 1926. Apart from tourists, it also attracts crowds of Spaniards, who busily move about between its stands. [5] Another remarkable as set is the park that surrounds the Old Town and that was built in the riverbed of the Turia River, which had once flown through the area. After intensive flooding in 1957, plans to drain the old riverbed and to turn it into a highway were made. However, it was there, which would encircle the entive the whe would encircle the extre Old Town and The Old Town is doming the form of four to five-story townhouses with functions such as cafes and restaurants on their ground floors. The buildings of the Old Town are remarkly colourful. The town the loured plaster, ranging from yellow, which appears to be the predominant colour in this city, to shades of rose pink and blues. The decorating of the walls of the townhouses and for instance, the undersides of staircases, with colourful ceramic tiles depicting floral motifs, but sometimes also animals and people, is very popular here. It is a distinctive trait of this city, as it was once famous for producing ceramics.

Colour and decoration give the city an extraordinary amount of energy and somewhat alleviate the density of its development-the distances between the walls of buildings are sometimes as small as 3 metres (this is the minimum legally permissible distance).

\section{REgENERATION OF HOUSING AND PUBLIC} SPACE IN THE HISTORICAL TISSUE OF THE CITY Urban analyses of a number of dilapidated and de cayed sites within Valencia's Old Town led to a series of ultimate conclusions, two of which took centre stage. Valencia's historic urban tissue lacks greenery and public spaces meant for the city's residentsplaces which could facilitate meetings between them and their activity. All of the designs prepared by the team of students from the Faculty of Architecture of the Cracow University of Technology were, therefore, tasked with solving this problem and proposing in-
teresting and functional projects that the city needs.

\subsection{Complex of two service buildings $[6,7]$}

The complex that is the subject of the project is composed of two new buildings: a New Technologies Centre ${ }^{1}$ and a Mediatheque ${ }^{2}$. Both were placed in the immediate vicinity of existing buildings, closing the square with their massing and continuing existing niejaccego $w$ zespole czteroosobowym.' Lokalizacja daje mozilwośc do stworzenia przestrzeni przeznaczonych na użytek miloszkanców, koórych jak juź wspomniano, w obrębie starego miasta brakuje. Ze względu na zly stan techniczny obiektow znajdujących się na tereni projektowym, zaproponowano nowe rozwiązania architektoniczne i aranzację terenu z poszanowaniem dla pierwotnej kompozyci

Centrum Nowych Technologii jest budynkiem sześciokondygnacyjnym $z$ tarasem na trzecim piętrze dostępnym dla odwiedzających. Forma Centrum jest nawiązaniem do lokalnego archetypu - podziały bryly naśladują charakte rystyczne rytmy otaczających go kamienic odznaczając see wy azn ka stalowa. Media za zaś jest budyn. por czerokndyczenie budynu nawazue do bogtej historii ceramik

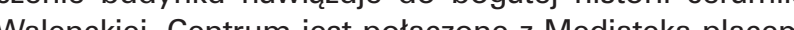
stanowiacym reinterpretacie funkcii obecrie pethionych przez teren projektowy, starajacym sie je uporzadkowac i poprawić ich jakość, gtównie jako plac zabaw dla dzieci i przestrzeń do organizacji wydarzeń publicznych. Pod całym placem zaprojektowano parking podziemny stanowiaccy transpozycje funkcij obecnie pełnionej przez tere projektowy. Wyjście z parkingu możliwe jest przez pawilon również zaprojektowany w bezpośrednim sasiedztwie istniejącego budynku. Pełni on również funkcje magazynu na elementy matej architektury wykorzystywane w ramach wydarzeń publicznych.

\section{Goowne założenia projektowe}

Obiekt Centrum Nowych Technologii wyróżnia się na tle otaczającej zabudowy, starając się jednak dopasowac do istniejacych reguł zarowno wysokoscią jak i modułem konstrukcyjnym. Głowną atrakcją ma stanowic wnętrze, zachęcające mieszkańców do częstego odwiedzania ispędzania wolnego czasu na jednym z poziomów tematycznych. Idea zróznicowanego programu inspirowana byla klimatem samego miasta, niesamowicie rożnorodnego, zarówno w skali poszczególnych dzielnic, jak pojedynczych kamienic. Częste występowanie sztuk ulicznej, festiwale jak las Fallas i sama w sobie kultura spędzania wolnego czasu poza domem sugeruja, iż tego typu obiekt móglby znaleźc swoich odbiorców.

W projekcie Mediateki skupiono się na stworzeniu kilku przestrzeni kreatywnych, ktore znajduja sie na oddzielw której moina sie swobodnie poruszá G Gómna de cyzja projektowa jest wykorzystanie na catej elewacil

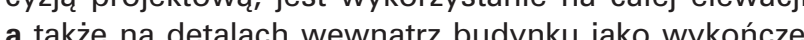
nia ceramiki, tak charakterystycznej dla samej Walencil. Bryła budynku składa się z dwóch różniacych sie od sie bie cześci. Minimalistyczny prostopadłościan zdaje sie unosić nad placem. Efekt lewitacji uzyskany zostat dzie ki cofnięiu cześci parterowej w stosunku do górnych kondygnacji oraz wykorzystaniu wspornika, który unosi połowę budynku nad ziemie.

2.2. Centrum Sztuk Wizualnych i Performance [8, 9] Dominującym kryterium w procesie projektowania Centrum Sztuk Wizualnych i Performance było stworzenie frontages. The urban design section of the project assumptions and analyses of the extant state of the site had been performed in a four-person team ${ }^{4}$. The site offers the possibility for creating spaces mean to be used by residents, whose presence in the Old Town-as it has already been mentioned-is insufficient. Due to the poor technical condition of the buildings at the site, new architectural solutions and site development were proposed, designed so as to respect the original composition.

The New Technologies Centre is a six-storey building with a terrace on the third floor, which is accessible to visitors. The form of the Centre is a reference to the the distinct rhythms of its surrounding townhouses, the distinct rhythms of its surrounding townhouses, clearly visible on the white facade, covered with a perforated steel mesh. The Mediatheque is a four-storey bulding with a rooftop terrace. The form and finishes ceramich. The Cente is linked with the Meliatheque

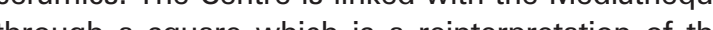
functions aurenty fulilled by the project site and an

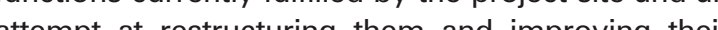
aualiy a rimaily as a playground for childen and a space for organising public events.

\section{Primary design assumptions}

The New Technologies Centre stands out from the surrounding buildings while trying to blend into extant rules both with its height and structural module. Its interior is meant to be its primary attraction, encouraging residents to frequently visit it and spend their free time on one of its themed levels. The concept of its varied programme was inspired by the atmosphere of the city itself, which is remarkably diverse, both on the scale of its individual districts and the festivals such as las Fallas and the culture of spendof building could find an audience.

The design of the Mediatieque foused on creating series of creative spaces which were placed on separate levels within the building, while simultaneously creating a coherent whole, in which one could freely move around. The main design decision was to use ceramic finishes, which are so distinct of Valencia, on the entire facade and in the details inside the building. The massing of the building is composed of two parts that are different from one anoth er. The minimalist cuboid appears to hover above the square. The effect of levitation was obtained thanks to setting back the ground floor section relative to raises half of the building above the ground.

\subsection{Visual Arts and Performance Centre $[8,9]$}

The dominant criterion in the process of designing the Visual Arts and Performance Centre was creating

in reference to Valencia's traditional model of a city 
przyjaznej dla mieszkańców przestrzeni miejskiej w nawiązaniu do tradycyjnego modelu placu miejskiego w Walencji. Projelt zaklada pozostawienie istniejących na obszarze funkcji takich jak parking czy plac zab dzieci oraz poszerzenie programu funkcjonalnego o dodatkowe aktywnosci, mając jednak na uwadze historyczny układ urbanistyczny i otaczającą zabudowę. Plac jest miejscem interakcji i integracji wszystkich grup wiekowych począwszy od dzieci (plac zabaw), przez studentów i dorosłych (miejsca do nauki, pracy, scena plenerowa ścianka z muralami) po osoby starsze (stanowiska do gry w szachy, miejsce relaksu). Istniejace obecnie na placu funkcje zmieniaja swoją formę, dzięki czemu stanowia integralna czessc przestrzeni miejskiej i są bardziej atrakcyjne dla odwiedzajacych. Zalożenie urbanistyczne za-

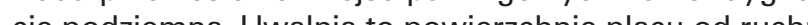
je podze o użytkownikom. Umieszazon zostaty na nim charakterystyczne dla Walencii akcenty w postaci zieleni wysokie i elementów wodnych oraz min ścianka do tworzenia murali, bedacych nieodzownym elementem miejkiego krajobrazu tego miasta. Charakterystycznym elementem dla omawianego placu jest znajdujacy sie we wschodniej cześci, wydzielony murem zespół zieleni wysokiej. Stanowi on duży potencjat dla tej okolicy, jednak jego obszar nie jest dostępny dla przechodniów. W projekcie założono otworzenie tego terenu oraz zintegrowanie go z pozostałą częścią placu. Efektem tego działania jest likwidacja bariery wizualnej pomiędzy wnętrzem obszaru a otaczającą go zabudowa.

\section{Główne założenia projektowe}

Głownym załozeniem kompozycyjnym jest wzmocnienie granic placu porzez uzupenienie ubytow whistorycznym ukladzie zabudowy srodmiejskiej powstałym po częsciowym zawaleniu/wyburzeniu dawnej zabudowy. Pozwala to na wytworzenie kameralnej przestzen stanowiącej integralną przestrzen VAaP Center. Północna pierzeja zostaje wydłużona poprzez umieszczenie tam jednego $z$ budynkow warsztatowo wystawienniczych, "doklejonego" do istniejącej ściany pożarowej kamienicy. Wytorzone w ten sposobb zostało wąskie przejście na plac - rodzaj bramy wytworzonej przez ścianę no woprojektowanego budynku a zespot istniejącej zielen wysokiej - stopniowo rozszerzajace się w Kierunku jego nowi pierzeja istniejacego cingu kamienic dopetnionego widowni perowa umiezczona na dachu nod zjazdem do parkingu podziemnego. Od strony wschodnie płynna granice stanowi zieleń stanowiaca istotny aspek kompozycyiny nie bedac bariera wzrokowa. Plac silni otwiera sie strone potudniowa od której naplyw ludzi jest naibardziej intensywny. Projektowany w tej cześci Budynek Drzewo 5 swym obtym ksztattem wyznacza si ną linię kompozycyjną naprowadzajaca przechodniów do wnetrza przestrzeni urbanistycznej. Obiekt ma po przez swoją formę prowadzić dialog z miastem, budzic kreatywność, mówić o problemach, poruszać tematy tabu, wyrażać emocje i treści. Budynek jest ekologiczny i ekonomiczny square. The project assumes leaving functions such while keeping in min the historical urban layout and the surrounding buildings. The square was designed as a place where al age groups interact and integrate, starting with chidren (the playground), through students and adults (places for studying, working, an open-air stage, a wal with murals) to seniors (chess-playing facilities, places where one can relax). The functions that existed at the square would change their form, which is why they would constitute an integral part of urban space and become more attractive to visitors. The new urban layout assumed the relocation of parking spaces to an underground level. This world free up the space of the fort to its users. The project assumed the placem accents that ar distinct of Valencia in the form of toll greenery and water features, as well as, among others, a wall for creating murals, which are an inseprable element of its cityscape. A fenced-off complex of tall greenery located in the square's eastern section, is its characteristic element. It creates a great deal of potential for this neighbourhood; however, it is not accessible to passersby. The design project assumed opening this area and integrating it with the remainin part of the square. The effect of this measure would be the removal of a visual barrier between the interior of the area and the buildings that surround it.

\section{Primary design assumptions.} The primary compositional assumption was to
strengthen the borders of the square by filling in the gaps in the historical layout of inner-city buildings, which had appeared after the partial demolition/collapse of historical structures. This made it possible to create a cameral space that would form an integra element of the VAaP Centre. The northern frontag was extended by placing one of the workshop and exhibition buildings there, "glueing it" to the existing firewall of a townhouse. This created a narrow passage to the square-a type of gate formed by the wal of the newly-designed building and the complex of existing tall greenery-gradually widening in the direction of its central section. The frontage of an existing sequence of townhouses that is supplemented by open-air audience stands on the roof above the driveway down to the underground parking facieast, a fluid border was formed by greent. From the east, a fuid border was formed by greenery, which a visual barrier. The square has a powerful opening to the south from where the flow of people is the most intense. The Tree Building ${ }^{5}$ that was designed there would establish a strong compositiona lin that would lead pedestrians to the interior of the urban space. The structure was meant to enter into a dialogue with the city through its form, stimulating creativity and communicating problems, touching taboo subjects, expressing emotions and messages.
Drugi obiekt warsztatowo-wystawienniczy ${ }^{6}$ sam w sobie jest formą performance. Odzwierciedla więc wyglądem ewnętranym zawartą wewnątrz funkcję. Wyposazony został on w przesuwne częsci konstrukcyjne w formi funkcjonalnych kostek. Ruchome elementy budynk pozwalają na elastyczne dostosowanie przestrzeni do potrzeb uzytkownikow. Powierzchnia uzytkowa zmieni się w zalezności od sposobu wykorzystania wewnętrzne przestrzeni. Może ona zostać powiększona w celu organizacji większych wydarzeń kulturalnych bądź zmniejszona $w$ celu oszczędnosci energetycznej - jest to jednak dzlalanie nie mające wplywu na powierzchnię jaka budynek zajmuje w poziomie parteru. Co za tym idzie uwolniona zostaje większa ilośc przestrzeni publiczne wo polo rzécby oraz malarstwa, a takie przestrzenie wystawiennicze i ogólnodostępną przestrzeń pracy.

2.3. Wielofunkcyjny budynek użyteczności publiczne [10, 11]

ematem opracowania jest wielofunkcyjny budynek użyteczności publicznej przedstawiony w dwóch wariantach. Jeden z nich to Mediateka7, łącząca funkcje małe biblioteki wraz z przestrzenią do coworkingu i zapleczem kawiarnianym, drugi zaś to dwuczęściowy budynek w którym znajdują się przestr

poczynku dla studentów ${ }^{8}$. Działka przeznaczona na projekt znajduje się w ścisłym historycznym centrum Walencji, które charakteryzuje się niezwykle ciasnym średniowiecznym układem (a) nistycznym. Działka ta to niemal idealny prostoká troczony $z$ trzech stron wąskimi ulicami o szerokosci $3,5 \mathrm{~m}$. W identycznej odległości znajduja się sąsied.

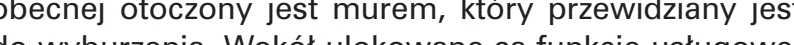
do wyburzenia. Wokó ulokowane sa funkcje usługowe, sakralne. W ścisłym sąsiedztwie znajduje sie mały placyk przed kościołem oraz większy historyczny plac, na którym obecność węzła komunikacyjnego dla autobuSów miejskich sprawia, iż przestrzeń ta nie jest przyjazn dla pieszych mieszkanców iturystów. Brak jest w pobliž tu też budynków użyteczności publicznej, np. biblioteki.

\section{Główne założenia projektowe}

Projekt pierwszy łączy funkcję budynku usługowego zewnętrznej przestrzeni publicznej $i$ swoistego zielonego ogrodu. Zgodnie z założeniami parter budynku ma być podniesiony tworząc ogólnodostępną przestrzen publiczną. Podobnie rzecz ma się z tarasem na dach budynku, który podobnie pełnić będzie funkcję ogrodu kawiarnianego i przestrzeni publicznej. Parametryczna struktura słupów ma stanowić stelaż dla roślin pod budynkiem tworzacych gesty „las". Elewacja na bazie trójkatów ma także stanowić pretekst dla utworzenia na nie wiszacego ogrodu wertykalnego. Cztery wewnetrzne piętra mają być przeznaczone na bibliotekę, przestrze coworkingowa oraz food court. W trzonie komunikacyj nym znajdą się toalety, zaplecza, szyby windowe oraz
The building is both eco-friendly and cost-efficient. formance form in and of itself. Therefore, its externa wearance reflects the function contained within. was equipped with movable structural components in the form of functional cubes. The movable elements of the space the nsable floor area changes an cultural in - or contracted to minimise energy consumpbuilin's forr, this is not something that affects the lic space is freed up to result, a large amount of pubin front of the building. and cinem hall, workhop spcus for studying phoography, sculpture and painting as well as exhibition spaces and a freely accessible workspace.

2.3. Mixed-use public building $[10,11]$

The subject of the project is a mixed-use public building, presented in two alternative variants. The first is a Mediatheque ${ }^{7}$, which combines the functions of a small library with a co-working space and a coffee shop, while the second is a two-part building that houses spaces for working, studying and rest for students ${ }^{8}$. The project site is located in the strict historical centre of Valencia, which is characterised by a remarkably cramped Medieval urban layout. The plot is an almost perfect rectangle, surrounded on three sides by narrow streets with a width of $3,5 \mathrm{~m}$. 17 to $18 \mathrm{~m}$ tall buildings are placed at the same distance away from its borders. The site is currently surrounded by a wall that is to be the site, there are functions such as serves, stores and gastronomy, a museum, as well as religious bulldings. There is a small square in front of a church nearby, as well as a larger, historical square, where the presence of a circulation node for municipal buses causes the space to be unfriendly to walking pedestrians and tourists. There is a lack of recreational are also no public buildings, e.g. a library.

\section{Primary design assumptions.}

The first project combines the functions of a service building, an external public space and sort of a green garden. According to the design assumptions, the ground floor of the building is to be raised, creating freely accessible public space. The matter is to be rof, which is likewise to fulfithe fun the buld hing's drinking garden and that of a public space. The parametric structure of the building's column is mean act as a frame for plants to climb, creating a dense "forest" under the building. The triangle-based fa"code is aso to act as a pretext for creating a vertica hanging garden on its surface. The building's four internal storeys are to feature a library, a co-working space and a food court. The circulation core will contain toilets, backrooms, elevator shafts and stairwells. Level - 1 was designed as a technical and storage level, 
klatki schodowe. Kondygnacja -1 została przewidziana jako plętro techniczno-magazynowe, z przestzeniami chu nadbudowki znajdują się miejsca na insta matyzacyjne i odnawialnych żródeł energii. Bryła budynku ma być szklanym prostopadłościanem z betonowym trzonem komunikacyjnym. Piętra od 1-4 obłożone sa zewnętrzną parametryczną elewacją na bazie nieregularnych trójkątów. Ściany mają być porośnięte cieniolubny mi roślinami i pnączami. Dach zaprojektowano jako tara częściowo ukryty pod strukturami parawanowymi, i dającymi cien w upalne dni. Tarasy wyposażone $w$ "zielon ściany działowe oraz barierkę będącą przedłużeniem struktury elewacji. Uniesienie cięzkiej bryły na lekkich

lofung budynek wielo ści. Jego bryła została zdefiniowana poprzez istnieąe kierunki oraz otwarcia widokwe. Doptkozo Kierunk gtównych ulic dochodzacych do dziatki oraz otwarcia widokowego na zabytkowy kościót wyznaczyły otwarta przestrzeń motego placu pomiedzy obiezy czéćiam budynku, Obiekt składa sie z dwóch pracowni, przestrzeni konferencyjnych, oraz otwartych przestrzeni do indywidualnej nauki lub odpoczynku. Elewacje miaty być syntezą i próbą modernistycznego podejścia do istniejących podziałów elewacyjnych istniejących obok kamienic historycznych.

\section{PODSUMOWANIE}

Wyjazd studialny studentów Wydziału Architektury Po litechniki Krakowskiej umozliwi rozmowy z przedstawcielami Cardinal Herrera University w celu skonfrontowania wnioskow z analiz urbanistycznych, które studenci przeprowadzili in situ oraz był okazja do zadania pytan odnośnie warunków i wymagan lokalnych. Rozmowy o terenie projektowym poprzedziła wycieczka po terenie campusu oraz zapoznanie się z lokalnymi metodami nauczania i wystawą prac dyplomowych. Wyjazd zakończy się zaproszeniem uczestników na międzynarodowe warsztaty organizowane pod patronatem Cardinal Herrera University. Zdobyte informacje dały możliwość poczucia na własnej skórze lokalnego klimatu, i odnalezienia ge nus loci miejsca. Efektem warsztatów bylo podjęcie decyzji odnosnie wyboru jednej z sledmiu proponowanych programu oraz skali projektownych budynów.

z i zwiedzajacych muzea. Chcac dotrzeć do nich jabyt szerszego grona odbiorców, twórcy wyrażaja swoje przekonania poprzez sztuke uliczna tworzac fascynuja ce murale na pustych ścianach i bramach garażowych. Rysunki te tworza specyficzny klimat i stanowia wazny element miasta. Sa głosem mieszkańców, szczerym, autentycznym i niekomercyinym. Sa ozdobą miasta i jego charakterem. Sztuka uliczna jest także głosem w kwesti spraw bieżących, sytuacji politycznej czy ekonomicznej, pewnych trendów lub tendencji dotyczących całego miasta lub nawet świata. Potrzebne jest miejsce na with spaces for conservation work. The level of the will house the HVAC and renewable ene tion installations. The massing of the building is to be a glass cuboid with a concrete circulation core. Floors 1 through 4 were designed as clad with a parametric facade based on irregularly-shaped triangles. The walls are to be covered by plants that like shade, as well as vines. The roof was designed as a terrace, partially covered by screen-like structures that provide shade during hot days. The terraces were equipped with "green partition walls" and a railing, which is an extension of the structure of the facade. The light columns that the massing is supported by give it an air of lightness. The second design presents a two-part mixed-use building, which is a four-storey structure with a terrace in addition, the directions of the main strie to guests. verge at the plot as well as that of a visual opening onto he nearby historical church, outlined the open space of small sy her between both parts of the building. The tructure is composed of two workshops, confer. The paces, as well as open spaes for individual studying or rest. The facades were to be a synthesis and an atempt at a modernist approach to the facade divisions of the nearby historical townhouses.

\section{CONCLUSIONS}

The study trip that the students of the Faculty of Archiecture of the Cracow University of Technology wer on made it possible to engage with representatives of the Cardenal Herrera University so as to confront the conclusions drawn from urban analyses that the students carried out on-site and was an occasion to ask questions concerning local conditions and requirements. The discussion on the project site was preceded $y$ a trip around the campus grounds and familiarising with local teaching methods and a diploma project exhibition. The trip ended with an invitation to an international workshop organised under the patronage of he Cardenal Herrera University being extended to the participants. The information the students had gained enabled them to personally experience the local atmosphere and discover the genius loci of the place. The workshop resulted in making a decision concerning selecting one of the seven plots proposed by the Cardenal Herrera University, the planned programme and the scale of the buildings that were being designed.

Thousands of tourists from all over the world visit $\mathrm{Va}$. thia every year-walking, marvelling at its heritage as well as to reach a wider audience, artists expres their convictions through street art, creating fascinating murals on empty walls and garage doors. The drawings create a distinct atmosphere and are an im portant element of the city. They are the voice of its esidents, an honest, genuine and non-commercia voice. They are the city's ornament and its character Street art is also a voice on current matters, the politica or the economic situation, concerning certain trends or tendencies that affect the whole city or even the entire sztukę tymczasową, ekspresyjną i eksperymentalną. Miejsce, w ktorym każdy z mieszkańców może wyrazić siebie, zorganizowac pewien manifest, poruszyc swój problem i zainteresowac tym innych. Obse wując społeczeństwo miasta można się przekonac o jego temperamencie, otwartości i kreatywności. Hiszpanie przywiązują duzą wagę do życia towarzyskiego. Uwielbiają spotykac się ze znajomymi w kawiarenkach, dyskutować i udzielać się towarzysko. Otwarte, dostępne dla wszystkich przestrzenie publiczne są idealnym miejscem wymiany poglądów Miejsca, do których bez względu na wiek czy status społeczny można przyjść, porozmawiać, dowiedzie się czegoś o innych i wyrazić siebie stanowią ważny punkt miasta.

Wszystkie te spostrzeżenia okazały się bezcenne $d$ uzyskaniu bardzo wysokiej ich jakości.

PRZYPISY

1 Projekt dyplomowy, 2019 wykonany na Wydziale Architektury Poli-
techniki Krakowskiej, autor: Filip Sierak, promotor: dr hab. Inż: arch Magdalena alagietto-Kowalczyk, prof. PK, wspótpromotor: dr inż. arch.
Bogdan Siedelecki 2 Projekt dyplomowy, 2019 wykonany na Wydziale Architektury Po-
litechniki Krakowskiej, autor: Piotr Dziewierz, promotor: dr hab. Inż.
arch. Mariusz Twardowski, wspotipromotor: dr inż. arch. Bogdan Sied$\operatorname{arch} . \mathrm{M}$
lecki

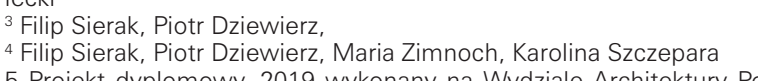

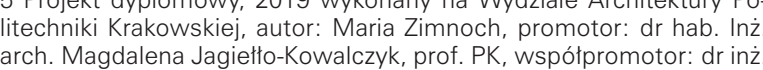
arch. Bogdan Siedlecki
6 'Projekt dyplomowy, 2019 wykonany na Wydziale Architektury Pol.

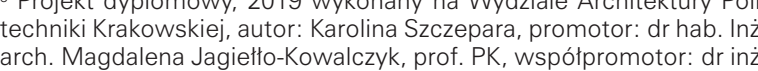
arch. Boodan Siedlecki 19 mykonany. 7 Projekt dyplomowy, 2019 wykonany na Wydziale Architektury Po-
litechniki Krakowskiei, autor: Michat Siupiki promotor: dr hab. Inz
arch Magdalena Jagietto-Kowalczyk, prof PK, wspótpromotor: drinż

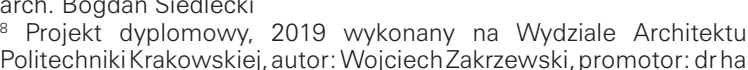

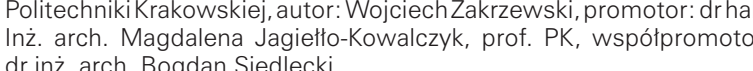

LITERATURA

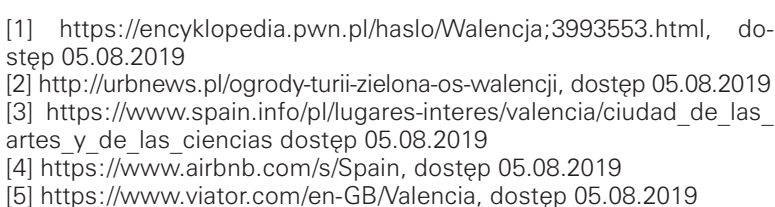

world. A space for temporary, expressive and experimental exs the problem and inspire interest in it in others. When observin the city's community, we can see its temperament, openness and creativity for ourselves. The Spanish attach a lo of significance to social life. They love to meet their friends and acquaintances at cafes, to take part in discussions and to be socially active. Open, freely accessible public spaces are the perfect places to exchange views. Places that can be entered regardless of one's age or social status to talk, to learn something about others and to express oneself, conAll of an important element of the city.

All of designs and in their high-quality preparation.

ENDNOTES

Diploma design project, 2019 , prepared at the Faculty of Architecture
of the Cracow University of Technology, author: 2 Diploma design n roject, 2019 , prepared at the Faculty of Architecture
of the Cracow University of Technology, author: Piotr Dziewierz, superof the Cracow University of Technology, author: Piotr Dziewierz, super-
visor: dr hab. Inż. arch. Mariusz Twardowski, co-supervisor: dr inż. arch. ${ }_{3}$ Filip Sierak, Piotr Dziewier 2,

${ }^{4}$ Filip Sierak, Piotr Dzievierz, Maria Zimnoch, Karolina Szczepara
${ }^{5}$ Diploma design project, 2019, prepared at the Faculty of Architectu

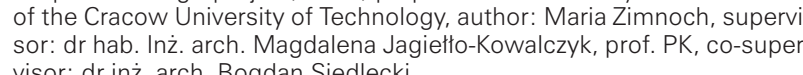
${ }^{-}$Diploma design project, 2019, prepared at the Faculty of Architectusupervisor: dr hab. Inż. arch. Magdalena Jagietto-Kowalczyk, prof. PK. co-supervisor: dr inzi. arch. Bogdan Siedlecki
7 Diploma design project, 2019, prepared at the Faculty of Architecture 7 Diploma design project, 2019 , prepared at the Faculty of Architecture
of the Cracow University of Technology, author: Michat Siupik, supervi-
sor: dr hab. Inż. arch. Magdalena Jagiefto-Kowalczyk, prof. PK, co-super-

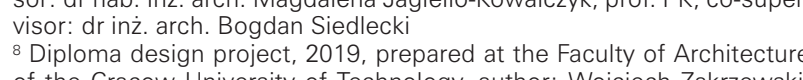

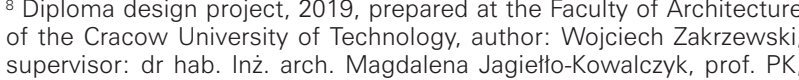
co-supervisor: dr inz. arch. Bogdan Siedlecki
colit

BIBLIOGRAPHY

[1] https://encyklopedia.pwn.pl/haslo/Nalencja;3993553.html, acces
sed: 05.08.2019 [2] http://urbnews.p//ogrody-turi-zielona-os-walencji, accesse

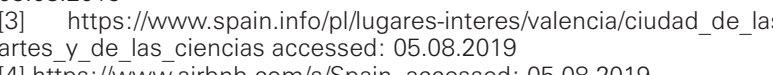

[4] https: I/WwW.airbnb. com/s/Spain, accessed: 05.08.2019
[5] https://WwW.viator.com/en-GBNalencia, accessed: 05.08.2019 